\title{
Reactive arthritis - an interdisciplinary issue
}

\section{Reaktywne zapalenie stawów - problem interdyscyplinarny}

\author{
Ewelina Biało-Wójcicka, Karolina Rutkowska, Kalina Wysocka-Dubielecka
}

Adult Dermatology Ward, Międzylesie Specialist Hospital, Warsaw, Poland

Oddział Dermatologii Dorosłych Międzyleskiego Szpitala Specjalistycznego w Warszawie, Polska

Dermatol Rev/Przegl Dermatol 2018, 105, 726-737

DOI: https://doi.org//0.5 | |4/dr.2018.80842

\author{
CORRESPONDING AUTHOR/ \\ ADRES DO KORESPONDENCJI: \\ Ewelina Biało-Wójcicka \\ Oddział Dermatologii \\ Dorosłych \\ Międzyleski Szpital \\ Specjalistyczny \\ ul. Bursztynowa 2 \\ 04-749 Warszawa, Polska \\ tel.: +48504694057 \\ e-mail: ewelbialo@poczta.onet.pl
}

\begin{abstract}
Reactive arthritis is an aseptic inflammation of synovium, tendons and fasciae triggered by an immunological reaction to a distant-site infection. It is usually asymmetric. It develops about 4 weeks after a prior infection of the genitourinary system (most often caused by Chlamydia trachomatis or Neisseria gonorrhoeae) or the gastrointestinal tract (most often: Shigella enteritidis, Salmonella typhimurium or Salmonella enteritidis, Campylobacter jejuni, Yersinia enterocolitica). A typical triad of symptoms includes: arthritis, conjunctivitis, and urethritis. Men aged 20-50 are most commonly affected. A considerable percentage of patients with reactive arthritis has the HLA-B27 antigen. Presence of the antigen heralds a more severe course of the disease and occurrence of articular complications. The disease may have a neoplastic course, sometimes it subsides without chronic consequences, and in some cases it evolves into other spondyloarthropathies.
\end{abstract}

\section{STRESZCZENIE}

Reaktywne zapalenie stawów to jałowe zapalenie błony maziowej, ścięgien i powięzi wywołane reakcją immunologiczną na zakażenie o odległej lokalizacji. Jest zazwyczaj asymetryczne. Występuje ok. 4 tygodnie po przebytym zakażeniu układu moczowo-płciowego (najczęściej wywołanym przez Chlamydia trachomatis lub Neisseria gonorrhoeae) lub przewodu pokarmowego (najczęściej Shigella enteritidis, Salmonella typhimurium lub Salmonella enteritidis, Campylobacter jejuni, Yersinia enterocolitica). Typową triadę objawów stanowią: zapalenie stawów, zapalenie spojówek i zapalenie cewki moczowej. Chorują najczęściej mężczyźni między 20. a 50. rokiem życia. U znacznego odsetka chorych z reaktywnym zapaleniem stawów występuje antygen HLA-B27. Obecność tego antygenu zwiastuje cięższy przebieg i wystąpienie powikłań pozastawowych. Choroba może mieć przebieg nawrotowy, czasami ustępuje, nie pozostawiając trwałych następstw, a w niektórych przypadkach ewoluuje $\mathrm{w}$ kierunku innych spondyloartropatii.

Key words: reactive arthritis, HLA-B27, keratodermia blenorhagicum, balanitis circinata, Reiter's syndrome.

Słowa kluczowe: reaktywne zapalenie stawów, HLA-B27, keratodermia blenorhagicum, balanitis circinata, zespół Reitera. 
Reactive arthritis $(\operatorname{ReA})$ is counted as a spondyloarthropathy, and includes non-infectious (nonpyogenic, aseptic) arthritis, which is a body's reaction to an infection at a distant organ, mainly in the gastrointestinal, genitourinary, or respiratory system [1]. According to the presently accepted nomenclature, this group is also referred to as seronegative spondyloarthropathies [2]. All disease entities belonging to the group of spondyloarthropathies have common clinical features. Apart from the absence of rheumatoid factor in serum, they include: lack of subcutaneous lumps, inflammatory lesions in sacroiliac joints and/ or spine, peripheral arthritis (asymmetric mono- and oligoarthropathies), skin and/or mucous symptoms, sight organ disorders, inflammatory lesions in the gastrointestinal tract, familial prevalence and overlapping clinical picture of related disease entities, and a more common presence of HLA-B27 (human leucocyte antigen B27) in the patients than in the healthy population [3].

Recent studies have not unambiguously determined a mechanism for appearing inflammatory lesions in this disease entity. The significance of genetic, infectious, and environmental factors is highlighted [4].

\section{OBJECTIVE}

To present a case of a patient with skin lesions that were initially diagnosed as allergic drug-induced dermatitis. During hospitalization and after a thorough examination of the patient and performance of additional tests, a ReA was diagnosed.

\section{CASE REPORT}

A 54-year-old male patient was transferred from Infectious Diseases Ward to Adult Dermatology Ward of Międzylesie Specialist Hospital in Warsaw in order to deepen diagnostics and treatment of the following widespread skin lesions: erythematous and exfoliating, erythematous and hydropic, and pustular with a tendency towards erythroderma. Lesions were most intense on feet and the left hand. Moreover, the following were present: considerable oedema, painfulness, massive hyperkeratosis of palms and soles, ungual lesions in the form of onycholysis, subungual hyperkeratosis, and yellowing of nail plates (figs. 1-3).

According to the patient's history, first skin lesions had appeared on the right index finger about 2 weeks before the patient was admitted to the Dermatology Ward. The skin lesions were accompanied by subfebrile state, arthralgia of hands and feet, shank oedema, and symptoms of conjunctivitis.

\section{WPROWADZENIE}

Reaktywne zapalenie stawów (reactive arthritis ReA) jest zaliczane do spondyloartropatii i obejmuje nieinfekcyjne (nieropne, jałowe) zapalenie stawów, które jest reakcją organizmu na zakażenia toczące się w odległym narządzie, głównie w układzie pokarmowym, moczowo-płciowym lub oddechowym [1].

Inne określenie tej grupy wg obecnie przyjętej nomenklatury to seronegatywne spondyloartropatie [2].

Wszystkie jednostki chorobowe należące do grupy spondyloartropatii mają wspólne cechy kliniczne. Poza nieobecnością czynnika reumatoidalnego w surowicy są nimi: brak guzków podskórnych, zmiany zapalne w stawach krzyżowo-biodrowych i/ lub w kręgosłupie, zapalenie stawów obwodowych (niesymetryczne mono- i oligoartropatie), objawy skórne i/lub śluzówkowe, zaburzenia w narządzie wzroku, zmiany zapalne $\mathrm{w}$ przewodzie pokarmowym, rodzinne występowanie oraz nakładanie się obrazu klinicznego pokrewnych jednostek chorobowych, częstsze niż u zdrowych ludzi występowanie antygenu HLA-B27 (human leucocyte antigen B27) [3].

Przeprowadzone badania nie określiły jednoznacznie mechanizmu powstawania zmian zapalnych w tej chorobie. Podkreśla się znaczenie czynników genetycznych, infekcyjnych oraz środowiskowych [4].

\section{CEL PRACY}

Przedstawiamy przypadek pacjenta ze zmianami skórnymi początkowo diagnozowanymi jako alergiczne polekowe zapalenie skóry. W trakcie hospitalizacji, po dokładnym zbadaniu chorego i wykonaniu dodatkowych badań ustalono rozpoznanie ReA.

\section{OPIS PRZYPADKU}

Mężczyzna 54-letni został przeniesiony z Oddziału Chorób Zakaźnych na Oddział Dermatologii Dorosłych Międzyleskiego Szpitala Specjalistycznego w Warszawie w celu poszerzenia diagnostyki i leczenia rozsianych zmian rumieniowo-złuszczających, rumieniowo-obrzękowych i krostkowych z tendencją do erytrodermii. Największe nasilenie zmian obserwowano w obrębie skóry gładkiej stóp i lewej ręki. Występował znaczny obrzęk, bolesność, hiperkeratoza dłoni i podeszew, zmiany paznokciowe $\mathrm{w}$ postaci onycholizy, hiperkeratozy podpaznokciowej i zażółcenia płytek paznokciowych (ryc. 1-3).

Jak wynikało z wywiadu, pierwsze zmiany skórne pojawiły w obrębie palca wskazującego lewej ręki ok. 2 tygodni przed przyjęciem na Oddział Dermatologii. Zmianom skórnym towarzyszył stan podgorączko- 


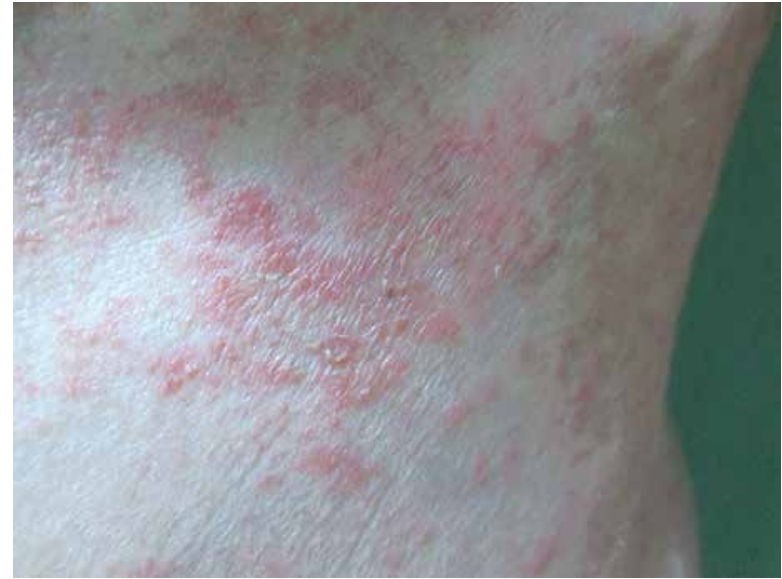

Figure I. Erythematous exfoliating skin lesion on the trunk Rycina I. Zmiany rumieniowo-złuszczające w obrębie skóry gładkiej tułowia

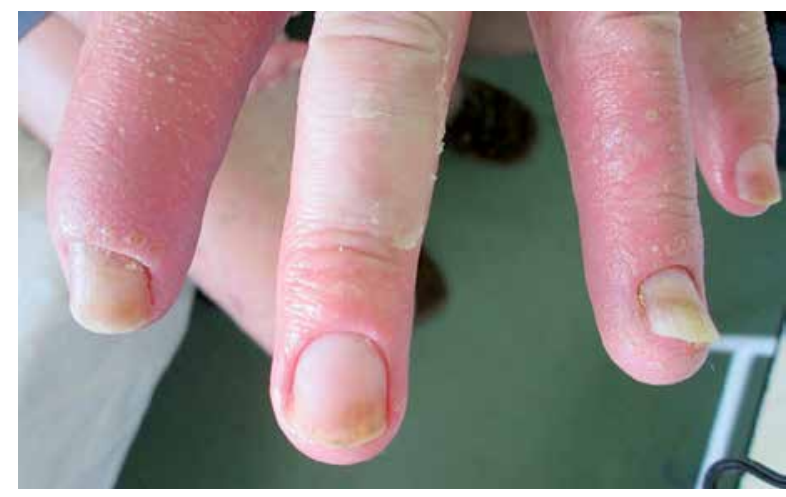

Figure 2. Pustular lesions on the left hand fingers and oedema of the index finger. Ungual lesions

Rycina 2. Zmiany krostkowe w obrębie palców lewej ręki oraz obrzęk palca wskazującego. Zmiany paznokciowe

Laboratory tests revealed macrocytic anaemia, accelerated erythrocyte sedimentation rate (ESR), slightly elevated C-reactive protein (CRP) concentration, increased activity of aspartate aminotransferase (AST), increased concentration of D-dimers and natriuretic peptide, hypoproteinemia, and vitamin $\mathrm{D}_{3}$ deficiency. Serological tests of HBsAg (hepatitis B surface antigen), anti-HCV antibodies (anti-hepatitis $\mathrm{C}$ virus antibodies), anti-HIV antibodies (human immunodeficiency virus antibodies), screening for syphilis, and urine cultures from urethra were negative. Chest $X$-ray was normal. Abdominal cavity ultrasound revealed fatty liver and slightly enlarged spleen; ultrasound (USG) of left hand tissues - oedema of the subcutaneous tissue of the back of the hand; major fluid reservoirs were not detected. Left hand X-ray showed soft tissue oedema, erosions, and periarticular bone atrophy in the distal interphalangeal joint of the left index finger, whereas feet $X$-ray did not reveal changes in the osseous system.

During hospitalization annular well-circumscribed and dark red erosions with slightly raised exfoliat-

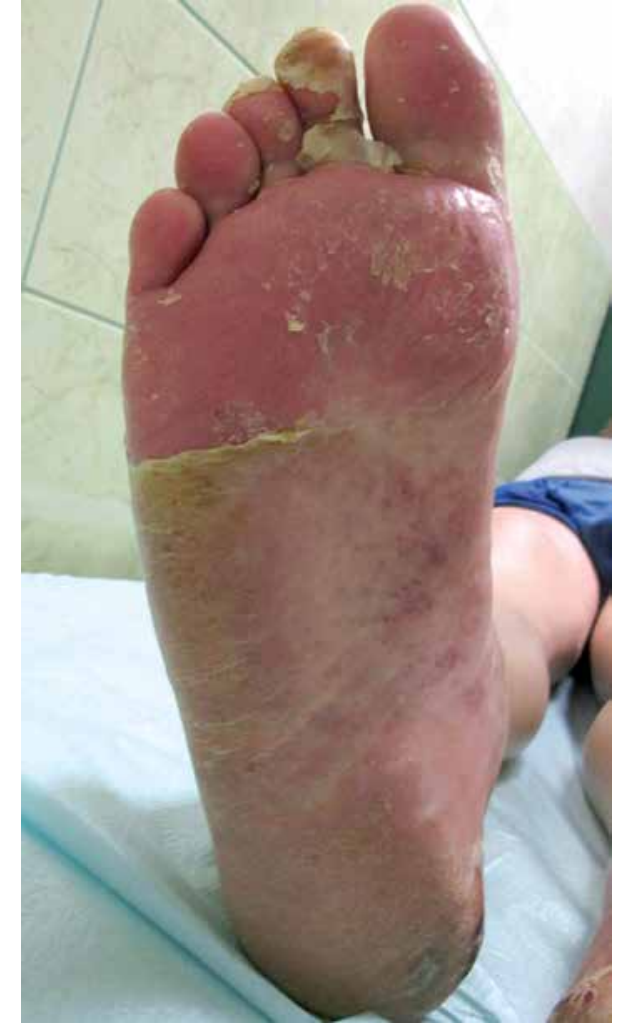

Figure 3. Hyperkeratosis of soles

Rycina 3. Hiperkeratoza podeszew stóp

wy, bóle stawów rąk i stóp, obrzęki podudzi oraz objawy zapalenia spojówek.

$\mathrm{W}$ badaniach laboratoryjnych stwierdzono niedokrwistość makrocytarną, przyspieszony opad czerwonych krwinek (odczyn Biernackiego - OB), nieznacznie zwiększone stężenie białka C-reaktywnego (C-reactive protein - CRP), podwyższoną aktywność aminotransferazy asparaginianowej (AST), aminotransferazy alaninowej (ALT), zwiększone stężenie D-dimerów i peptydu natriuretycznego, hipoproteinemię oraz niedobór witaminy $\mathrm{D}_{3}$. Badania serologiczne HBsAg (hepatitis $B$ surface antigen), przeciwciała anty-HCV (anti-hepatitis C virus antibodies), przeciwciała anty-HIV (human immunodeficiency virus antibodies), przesiewowe odczyny kiłowe, posiewy moczu były ujemne. $W$ badaniu radiologiczym (RTG) klatki piersiowej nie stwierdzono odchyleń. W badaniu ultrasonograficznym (USG) jamy brzusznej wykazano stłuszczenie wątroby i nieznaczne powiększenie śledziony, w USG tkanek lewej ręki - obrzęk tkanki podskórnej w części grzbietowej, nie wykryto większych zbiorników płynu. W badaniu RTG ręki lewej stwierdzono obrzęk tkanek miękkich oraz nadżerki i przystawowy zanik kostny w stawie międzypaliczkowym dalszym lewego palca wskazującego, natomiast w badaniu RTG stóp nie stwierdzono zmian w układzie kostnym.

W trakcie hospitalizacji na powierzchni żołędzi pojawiły się obrączkowate, dobrze odgraniczone, ciem- 


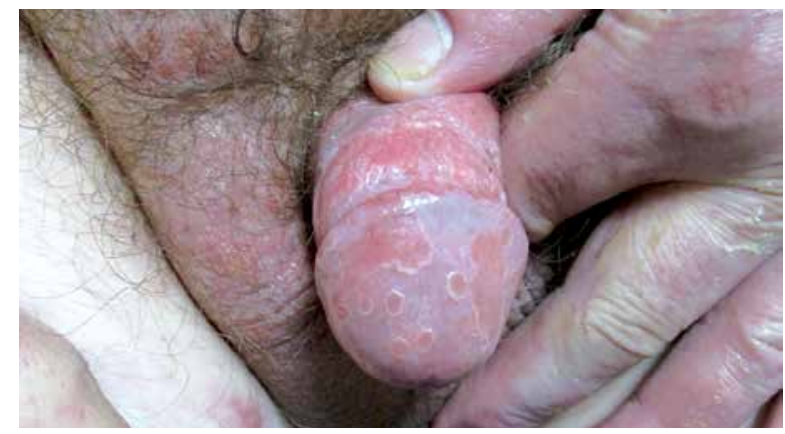

Figure 4. Balanitis circinata

Rycina 4. Obrączkowate zapalnie żołędzi

ing boarders appeared on the surface of the glans; these erosions are known in literature as circinate balanitis (fig. 4). Diagnostics was deepened to include examination of urethra smear by means of polymerase chain reaction (PCR) - presence of Chlamydia trachomatis deoxyribonucleic acid (DNA) was not revealed. However, presence of Campylobacter jejuni in the faecal matter, and presence of anti-Yersinia enterocolitica antibodies in serum IgA and IgG class with no clinical signs of a gastrointestinal infection were detected. The faecal culture contained faecal microbiota. Histopathological examination of skin sections showed hyperkeratosis, parakeratosis, presence of a micro-abscess from neutrophils within a parakeratotic focus, and slightly intensive infiltrations from mononuclear cells and neutrophils in the dermis.

The treatment included prednisone in the dose of $40 \mathrm{mg} /$ day $(0.5 \mathrm{mg} / \mathrm{kg} \mathrm{bw} /$ day), pantoprazole, nonsteroidal anti-inflammatory drugs (ketoprofen $150 \mathrm{mg}$ / day and dexketoprofen $50 \mathrm{mg} /$ day), and vitamin $\mathrm{D}_{3}$ supplements. After a gastrointestinal consultation, $1.5 \mathrm{~g}$ of azithromycin were administered once. Due to persisting arthralgia and presence of joint erosions, methotrexate in the dose of $15 \mathrm{mg} /$ week and folic acid in the dose of $15 \mathrm{mg} /$ week were included. A Doppler ultrasound of lower limb veins was performed due to oedema of both lower legs. Venous insufficiency and postphlebitic lesions in the veins of the right lower limbs were confirmed. Echocardiography showed a slight hypertrophy of the left ventricle. A consulting cardiologist introduced angiotensin-converting-enzyme inhibitors (ACEI). As a consequence of the applied treatment, local condition improved and symptoms were reduced. The patient was referred to Rheumatology Clinic in order to control the treatment and possibly deepen the diagnostics.

\section{DISCUSSION}

Descriptions of arthritis occurring after an infection have been present since antiquity. The condi- noczerwone nadżerki o lekko wyniosłych, łuszczących się brzegach, określane w piśmiennictwie jako circinate balanitis (ryc. 4). Poszerzono diagnostykę o badanie wymazu z cewki moczowej metodą reakcji łańcuchowej polimerazy (polymerase chain reaction - PCR) - nie stwierdzono kwasu deoksyrybonukleinowego (DNA) Chlamydia trachomatis. Obecne były natomiast antygen Campylobacter jejuni w kale oraz przeciwciała w surowicy przeciwko Yersinia enterocolitica w klasie IgA i IgG, bez klinicznych objawów infekcji żołądkowo-jelitowej. W posiewie kału wyhodowano florę fizjologiczną. W badaniu histopatologicznym wycinków skóry wykazano hiperkeratozę, parakeratozę, mikroropień $\mathrm{z}$ neutrofilów w obrębie ogniska parakeratozy oraz mało nasilone nacieki z komórek jednojądrzastych i neutrofilów w skórze właściwej.

$\mathrm{W}$ leczeniu zastosowano prednizon $\mathrm{w}$ dawce $40 \mathrm{mg} /$ dobę (0,5 mg/kg m.c./dobę), pantoprazol, niesteroidowe leki przeciwzapalne (ketoprofen $150 \mathrm{mg}$ / dobę i deksketoprofen $50 \mathrm{mg} /$ dobę), suplementację witaminą $\mathrm{D}_{3}$. Po konsultacji gastroenterologicznej podano jednorazowo 1,5 g azytromycyny. Ze względu na utrzymujące się dolegliwości stawowe i obecność nadżerek w stawach dołączono metotreksat w dawce $15 \mathrm{mg}$ tygodniowo i kwas foliowy w dawce $15 \mathrm{mg}$ tygodniowo. Wykonano badanie USG metodą Dopplera żył kończyn dolnych z powodu obrzęku obu podudzi. Stwierdzono niewydolność żylną oraz zmiany pozakrzepowe w żyłach kończyny dolnej prawej. Echokardiografia wykazała niewielki przerost lewej komory serca. Konsultujący kardiolog wprowadził inhibitory konwertazy angiotensyny (angiotensin-converting-enzyme inhibitors - ACEI). W wyniku zastosowanego leczenia uzyskano poprawę stanu miejscowego oraz redukcję objawów podmiotowych. Pacjenta skierowano do Kliniki Reumatologii w celu kontroli leczenia oraz ewentualnego poszerzenia diagnostyki.

\section{OMÓWIENIE}

Opisy zapaleń stawów, które występują po zakażeniu, powstały już w czasach starożytnych. Scho- 
tion was described for the first time by Hans Reiter in 1916, and in 1942 it was accepted as a syndrome. Since 1977 arthritis connected with a prior infection has been known as reactive arthritis. What Reiter and his predecessors described is considered to be a classic triad of symptoms [5].

Reactive arthritis most often affects men aged 20 50, and people with present HLA-B27. HLA-B27 is a highly polymorphic molecule containing over 116 protein subtypes; HLA-B27:01 and B27:117 subtypes are best known. Currently, considering the antigen structure, the most similar to HLA-B27 is HLA-B40, B40:01 subtype to be more precise [6].

It is assumed that bacterial lipopolysaccharide antigens may show similarity to HLA-B27 epitopes. It is thought that the risk of developing $\operatorname{ReA}$ is 50 times higher in people with present HLA-B27 [7]. Moreover, the $\mathrm{Y}$ chromosome is a risk factor for developing ReA as a consequence of genitourinary tract infection. The morbidity ratio of men and women equals $10: 1$. On the other hand, considerably fewer men develop ReA as a consequence of intestinal infections [8].

Etiological factors most often include: Yersinia enterocolitica, Yersinia pseudotuberculosis, Salmonella typhimurium, Salmonella enteritidis, Shigella flexneri, Shigella sonnei, Campylobacter jejuni, Brucellae, Neisseria gonorrhoeae, Clostridium difficile and Chlamydia trachomatis as well as pneumoniae, Ureaplasma urealyticum, Borrelia burgdorferi. Also Helicobacter pylori, parvovirus B19, Herpes simplex virus (HSV), Varicella zoster virus (VZV), cytomegalovirus (CMV), and human immunodeficiency virus (HIV) are connected to or suspected to be associated with ReA. There are reports stating that ReA developed after application of a vaccine against influenza and intravesical administration of BCG (Bacillus Calmette-Guerin) strain during the therapy of urinary bladder neoplasms $[9,10]$. In 1/4 cases, an etiological factor fails to be identified. Reactive arthritis secondary to infections of the gastrointestinal track is most commonly described. Frequency of its occurrence is estimated at $1-7 \%$ of people who had a prior gastrointestinal tract infection [11]. German researchers determined ReA frequency in children after an infection with bacteria belonging to Salmonella group as very low, and explained it with differences in responses of the immune system in children and adults [12]. Other publications showed a positive correlation between the time of diarrhoea and risk of ReA occurrence [13].

Occurrence of all three symptoms is not a pre-requisite, and happens quite often. Nowadays - when infections spread depending on sexual activities and HIV - special attention has been paid to patients from risk groups who had arthritis and urethritis, and thus, a subtype of sexually acquired ReA (SARA) has been isolated. A direct relationship between SARA and rzenie, opisane po raz pierwszy przez Hansa Reitera w 1916 r., zostało zaakceptowane jako zespół w 1942 r. Od 1977 r. dla zapalenia stawów powiązanego z przebytym zakażeniem przyjęto nazwę reaktywne zapalenie stawów. To, co opisał Reiter i jego poprzednicy, uważa się za klasyczną triadę objawów [5].

Reaktywne zapalenie stawów dotyczy najczęściej mężczyzn między 20. a 50. rokiem życia, osoby $z$ antygenem HLA-B27. HLA-B27 jest wysoce polimorficzną cząsteczką zawierającą więcej niż 116 podtypów białek. Najlepiej zbadane są podtypy HLA-B27:01 i B27:117. Obecnie najbardziej podobny pod względem struktury antygenu HLA-B27 jest HLA-B40, dokładnie podtyp B40:01 [6].

Przyjmuje się, że lipopolisacharydowe antygeny bakteryjne mogą wykazywać podobieństwo $z$ epitopami antygenu HLA-B27. Uważa się, że ryzyko rozwoju ReA jest 50 razy większe u osób z obecnym antygenem HLA-B27 [7]. Również chromosom Y jest czynnikiem ryzyka rozwoju ReA wywołanego infekcją przenoszoną drogą płciową. Stosunek zachorowalności mężczyzn do kobiet wynosi $10: 1$, natomiast znacznie mniej mężczyzn zapada na ReA będące następstwem infekcji jelitowych [8].

Czynnikami etiologicznymi są najczęściej: Yersinia enterocolitica, Yersinia pseudotuberculosis, Salmonella typhimurium, Salmonella enteritidis, Shigella flexneri, Shigella sonnei, Campylobacter jejuni, Brucellae, Neisseria gonorrhoeae, Clostridium difficile oraz Chlamydia trachomatis i pneumoniae, Ureaplasma urealyticum, Borrelia burgdorferi. Również Helicobacter pylori, parwowirus B19, wirus opryszczki zwykłej (HSV), wirus ospy wietrznej, cytomegalowirus (CMV), wirus HIV mają związek lub są podejrzewane o związek z ReA. Istnieją doniesienia o wystąpieniu ReA po zastosowaniu szczepionki przeciwko grypie oraz po dopęcherzowym podaniu szczepu BCG (Bacillus Calmette-Guerin) $\mathrm{w}$ trakcie terapii nowotworów pęcherza moczowego $[9,10]$. W ok. 1/4 przypadków czynnik etiologiczny nie zostaje zidentyfikowany. Najczęściej opisywane są odczynowe zapalenia stawów wtórne do zakażeń przewodu pokarmowego. Częstość ich występowania wynosi 1-7\% wśród osób, które przebyły infekcje pokarmowe [11]. Badacze niemieccy określili częstość występowania ReA u dzieci po zakażeniu pałeczkami z grupy Salmonella jako bardzo niską, co tłumaczono różnicami w odpowiedzi układu immunologicznego dzieci i dorosłych [12]. W innych publikacjach wskazywano na dodatnią zależność między czasem trwania biegunki a ryzykiem wystąpienia ReA [13].

Wystąpienie wszystkich trzech objawów nie jest koniecznym warunkiem rozpoznania ReA. Obecnie - w dobie szerzenia się zakażeń w zależności od aktywności seksualnej oraz HIV - zwrócono uwagę na chorych z grup ryzyka, u których wystąpiło zapalenie stawów i zapalenie cewki moczowej, oraz wyodręb- 
HIV has not been shown, but a common co-existence of opportunistic infections (with Chlamydia trachomatis inter alia) in this group of patients, has. It should be noted that HIV-diagnostics for patients with ReA symptoms and possibly being at risk of developing a HIV-infection is necessary [14, 15].

A group of Canadian researchers analysed data from 1966-2006 published in PubMed/Medline database with regard to Campylobacter-associated ReA. It suggested ReA development in $1-5 \%$ of patients infected with Campylobacter, and in about $5 \%$ of these patients a chronic or recurrent disease course was described. Moreover, there is observed arthritis typical for ReA, i.e. aseptic arthritis accompanying an infection with Mycobacterium tuberculosis - called Poncet's disease [16, 17].

Lipopolysaccharide antigens of the outer cell membrane were found in synovial fluid and bioptate from the synovium in patients with ReA. It may indicate that structures of these bacteria are transferred from infection sites to joints. The ways of transfer and precise location in synovia have not been determined yet $[18,19]$.

Under the influence of transforming growth factor $\beta$ (TGF- $\beta$ ), pro-inflammatory cytokines, such as interleukin 6 (IL-6), and others, naïve T-cells differentiate into Th17 lymphocytes that produce interleukin 17 (IL-17), a pro-inflammatory cytokine. Interleukin 17 is confirmed to be present in synovial fluid of ReA-patients. Toll-like receptor 4 (TLR 4) responsible for recognizing lipopolysaccharides of Gram-negative bacteria exerts an influence on the inflammation [20, 21].

An asymmetric acute arthritis involving one or more joints is typical for ReA; it affects more often joints of lower limbs, but does not exclude inflammation of other joints, including the small ones, e.g. found in hands. An acute ReA onset with involvement of spine and sacroiliac joints is less commonly observed. Moreover, similarly to other spondyloarthropathies, enthesitis may develop. Enthesopathies may have various clinical symptoms such as: painfulness of the entire body, oedema of a finger (toe) or fingers (toes), enthesopathy of plantar aponeurosis, Achilles tendon, and symptoms of tennis and golfer's elbow. Wandering joint pain can also appear. Symptoms of mono-/oligoarthritis may be accompanied by general symptoms such as: an increase in body temperature, feeling unwell, lack of appetite, generalized muscle pain in $30-50 \%$ cases [22, 23].

Currently, diagnosing $\operatorname{ReA}$ is based on meeting the criteria for axial or peripheral spondyloarthropathy according to the Assessment of SpondyloArthritis International Society (ASAS) and connecting them with a prior infection of the urogenital or gastrointestinal system. ASAS' criteria from 2010 for axial and niono podtyp ReA nabytego droga płciową (sexually acquired reactive arthritis - SARA). Nie stwierdzono bezpośredniej zależności między zespołem SARA a zakażeniem HIV, ale stwierdzono częste współistnienie u tych chorych zakażeń oportunistycznych, m.in. zakażenia Chlamydia trachomatis. Należy zwrócić uwagę na konieczność diagnostyki w kierunku zakażenia HIV u pacjentów z objawami ReA należących do grup ryzyka zakażenia HIV [14, 15].

Grupa badaczy kanadyjskich przeanalizowała dane z lat 1966-2006 zamieszczone w bazie PubMed/ Medline dotyczące reaktywnego zapalenia stawów wywołanego zakażeniem Campylobacter (Campylobacter-associated ReA). Sugerowały one rozwój ReA u 1-5\% chorych zakażonych Campylobacter, a wśród tych chorych u ok. $5 \%$ opisywano przewlekły lub nawrotowy przebieg. Obserwuje się też zapalenie stawów typowe dla ReA, czyli aseptyczne, towarzyszące aktywnemu zakażeniu Mycobacterium tuberculosis - zwane chorobą Ponceta $[16,17]$.

Lipopolisacharydowe antygeny zewnętrznej błony komórkowej wykryto w płynie stawowym i bioptacie $\mathrm{z}$ błony maziowej $\mathrm{u}$ chorych na ReA. Może to wskazywać, że struktury tych bakterii przenoszone są z miejsca zakażenia do stawów. Sposób przenoszenia i dokładna lokalizacja w błonach maziowych nie zostały ustalone [18, 19].

Dziewicze limfocyty T pod wpływem m.in. transformującego czynnika wzrostu $\beta$ (TGF- $\beta$ ) i cytokin prozapalnych, takich jak interleukina 6 (IL-6), różnicują się w limfocyty Th17, które produkują interleukinę 17 (IL-17) o działaniu prozapalnym. Interleukinę 17 stwierdza się $\mathrm{w}$ płynie stawowym pacjentów z ReA. Na rozwój zapalenia wpływają receptory toll-like 4 (TLR 4) odpowiedzialne za rozpoznawanie liposacharydów bakterii Gram-ujemnych [20, 21].

Typowe dla ReA jest asymetryczne ostre zapalenie stawu lub stawów, częściej dotyczące stawów kończyn dolnych, co nie wyklucza zapalenia innych stawów, w tym drobnych stawów, np. rąk. Rzadziej obserwuje się ostry początek ReA z zajęciem stawów kręgosłupa i krzyżowo-biodrowych. Może również dochodzić, podobnie jak w przypadku innych spondyloartropatii, do zapalenia okolic przyczepów ścięgien, czyli tzw. enthesitis. Entezopatie mogą dawać wiele różnorodnych objawów klinicznych, takich jak bolesność całego ciała, obrzęk jednego lub wielu palców, entezopatia ścięgna podeszwowego, ścięgna Achillesa, objawy typu łokcia tenisisty i golfisty. Może występować wędrujący ból stawów. Objawom mono- i oligoarthritis mogą towarzyszyć objawy ogólne, takie jak wzrost ciepłoty ciała, złe samopoczucie, brak łaknienia, uogólnione bóle mięśni w 30-50\% przypadków [22, 23].

Rozpoznanie ReA obecnie opiera się na spełnieniu kryteriów spondyloartropatii osiowej lub obwodowej 
peripheral spondyloarthropathy are presented in figures 5 and 6 together with definitions of spondyloarthropathy features (table 1) [24].

Symptoms connected to the urogenital system include: urethrocystitis, cervicitis and adnexitis in women, and orchiepididymitis as well as prostatitis in men. Moreover, ReA may also develop secondary to an infection of the urogenital system with Chlamydia trachomatis - it is known is literature as Chlamydia-induced arthritis (CIA). Other microorganisms, i.e. Ureaplasma urealyticum and HIV, may also be reasons behind developing sexually acquired ReA known in literature as SARA. Infections in the urogenital system are often asymptomatic, and repeatedly give false negative bacteriological test results (e.g. urine cultures, cervical smear, or urethral smear in men), because microorganisms such as Chlamydia trachomatis and Ureaplasma urealyticum need special culture wg The Assessment of SpondyloArthritis International Society (ASAS) oraz powiązania ich z przebytym zakażeniem dróg moczowo-płciowych lub przewodu pokarmowego. Kryteria ASAS z 2010 r. spondyloartropatii obwodowej i osiowej przedstawiono na rycinach 5 i 6 wraz z definicją cech spondyloartropatii (tab. 1) [24].

Objawy ze strony układu moczowo-płciowego obejmują: zapalenie cewki moczowej i pęcherza moczowego, u kobiet zapalenie szyjki macicy i przydatków, a u mężczyzn - zapalenie jądra, najądrzy i gruczołu krokowego. Wskutek zakażenia układu moczowo-płciowego przez Chlamydia trachomatis może również wystąpić reaktywne zapalenie stawów, znane w piśmiennictwie jako CIA (Chlamydia-induced arthritis). Inne drobnoustroje, takie jak Ureaplasma urealyticum oraz HIV, mogą być również przyczyną rozwoju ReA przenoszonego drogą

Patients with $>3$ months back pain and age at onset $<45$ years/

Chorzy z bólem pleców trwajacym $>3$ miesięcy i w wieku $<45$ lat w chwili wystąpienia dolegliwości

Sacroiliitis on imaging* plus $\geq$ I SpA feature*** Zapalenie stawów krzyżowo-biodrowych (SKB) w badaniu obrazowym* $\mathrm{i} \geq \mathrm{I}$ cecha SpA**

* Sacroiliitis on imaging/Zapalenie SKB w badaniu obrazowym:

- active (acute) inflammation on MRI highly suggestive of sacroiliitis associated with SpA/aktywne (ostre) zapalenie w MRI silnie wskazujące na zapalenie SKB związane ze SpA - definite radiographic sacroiliitis according to modified NY criteria/potwierdzone radiologicznie zapalenie SKB wg zmodyfikowanych kryteriów nowojorskich or/lub

HLA-B27 plus $\geq 2$ other SpA features**/ HLA-B27 $\mathrm{i} \geq 2$ inne cechy SpA**

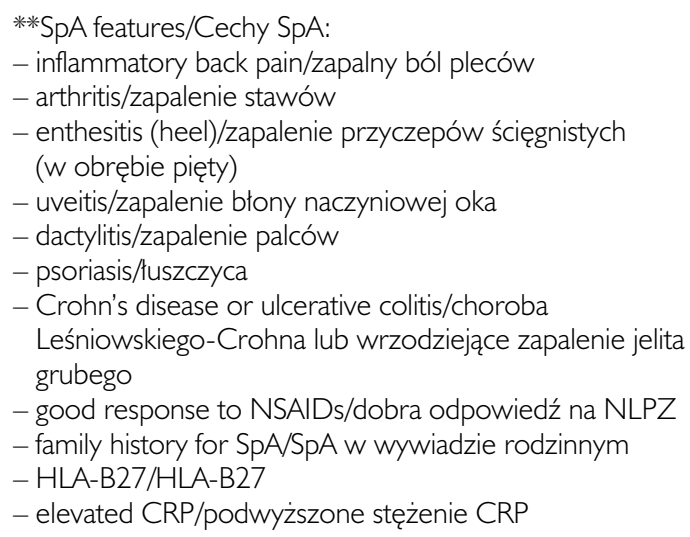

Figure 5. Classification criteria for axial spondyloarthropathy (SpA) according to the Assessment of SpondyloArthritis International Society (ASAS) [24]

Rycina 5. Kryteria klasyfikacyjne spondyloartropatii (SpA) osiowej wg The Assessment of SpondyloArthritis International Society (ASAS) [24]

Arthritis or enthesitis or dactylitis/

Zapalenie stawów lub przyczepów ścięgnistych, lub palców and/oraz

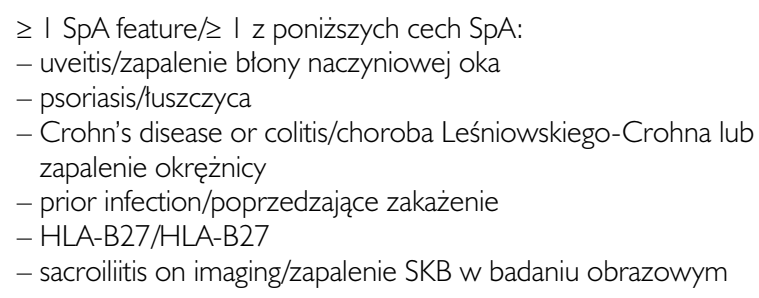

Figure 6. Classification criteria for peripheral spondyloarthropathy (SpA) according to the Assessment of SpondyloArthritis International Society (ASAS) [24]

Rycina 6. Kryteria klasyfikacyjne spondyloartropatii (SpA) obwodowej wg The Assessment of SpondyloArthritis International Society (ASAS) [24] 
Table I. Definitions of spondyloarthropathy (SpA) features [24]

\begin{tabular}{|c|c|}
\hline $\begin{array}{l}\text { Clinical } \\
\text { criteria }\end{array}$ & Definition \\
\hline $\begin{array}{l}\text { Inflammatory } \\
\text { back pain (IBP) }\end{array}$ & $\begin{array}{l}\text { IBP according to experts: } 4 \text { out of } 5 \text { of the } \\
\text { following parameters present: } \\
\text { I) age at onset }<40 \text { years } \\
\text { 2) insidious onset } \\
\text { 3) improvement with exercise } \\
\text { 4) no improvement with rest } \\
\text { 5) pain at night (with improvement upon } \\
\text { getting up) }\end{array}$ \\
\hline Arthritis & $\begin{array}{l}\text { Past or present active synovitis diagnosed by } \\
\text { a physician } \\
\text { Presence in first-degree or second-degree } \\
\text { relatives of any of the following: } \\
\text { 1) ankylosing spondylitis } \\
\text { 2) psoriasis } \\
\text { 3) uveitis } \\
\text { 4) reactive arthritis } \\
\text { 5) inflammatory bowel disease }\end{array}$ \\
\hline Family history & $\begin{array}{l}\text { Past or present psoriasis diagnosed by } \\
\text { a physician }\end{array}$ \\
\hline $\begin{array}{l}\text { Inflammatory } \\
\text { bowel disease }\end{array}$ & $\begin{array}{l}\text { Past or present Crohn's disease or ulcerative } \\
\text { endocolitis diagnosed by a physician }\end{array}$ \\
\hline Dactylitis & $\begin{array}{l}\text { Past or present dactylitis diagnosed by } \\
\text { a physician }\end{array}$ \\
\hline Enthesitis & $\begin{array}{l}\text { Heel enthesitis: past or present spontaneous } \\
\text { pain or tenderness at examination at the site } \\
\text { of the insertion of the Achilles tendon or } \\
\text { plantar fascia at the calcaneus }\end{array}$ \\
\hline $\begin{array}{l}\text { Uveitis } \\
\text { anterior }\end{array}$ & $\begin{array}{l}\text { Past or present uveitis anterior diagnosed by an } \\
\text { ophthalmologist }\end{array}$ \\
\hline $\begin{array}{l}\text { Good } \\
\text { response to } \\
\text { NSAIDs }\end{array}$ & $\begin{array}{l}\text { At } 24-48 \mathrm{~h} \text { after a full dose of NSAID the back } \\
\text { pain is not present anymore or much better }\end{array}$ \\
\hline $\begin{array}{l}\text { Lab or } \\
\text { imaging tests }\end{array}$ & Definition \\
\hline HLA-B27 & $\begin{array}{l}\text { Positive testing according to standard } \\
\text { laboratory techniques }\end{array}$ \\
\hline Elevated CRP & $\begin{array}{l}\text { CRP above upper normal limit in the presence } \\
\text { of back pain, after exclusion of other causes for } \\
\text { elevated CRP concentration }\end{array}$ \\
\hline $\begin{array}{l}\text { Sacroilititis on } \\
\text { X-ray }\end{array}$ & $\begin{array}{l}\text { Bilateral grade } 2-4 \text { or unilateral grade } 3-4, \\
\text { according to the modified New York criteria }\end{array}$ \\
\hline $\begin{array}{l}\text { Sacroiliitis on } \\
\text { MRI }\end{array}$ & $\begin{array}{l}\text { Active inflammatory lesions of sacroiliac } \\
\text { joints with definite bone marrow oedema or } \\
\text { osteitis suggestive of sacroilitis associated with } \\
\text { spondyloarthropathy }\end{array}$ \\
\hline
\end{tabular}

Tabela I. Definicje cech spondyloartropatii (SpA) [24]

\begin{tabular}{ll}
$\begin{array}{l}\text { Kryteria } \\
\text { kliniczne }\end{array}$ & \multicolumn{1}{c}{ Definicja } \\
\hline Zapalny ból & ZBP wg ekspertów: obecne 4 spośród \\
pleców (ZBP) & 5 następujących cech: \\
& 1) początek objawów w wieku < 40 lat \\
& 2) podstępny początek \\
& 3) poprawa po ćwiczeniach fizycznych \\
& 4) nieustępowanie bólu podczas odpoczynku \\
& 5) ból w nocy (z poprawą po wstaniu z tóżka)
\end{tabular}

Zapalenie Aktywne zapalenie błony maziowej obecnie stawów lub w wywiadzie, rozpoznane przez lekarza Obecność u krewnych pierwszego lub drugiego stopnia któregokolwiek z wymienionych:

I) zesztywniające zapalenie stawów kręgosłupa

2) łuszczyca

3) zapalenie błony naczyniowej oka

4) reaktywne zapalenie stawów

5) nieswoiste zapalenie jelit

\begin{tabular}{ll}
\hline Wywiad & Łuszczyca obecnie lub w wywiadzie, \\
rodzinny & rozpoznana przez lekarza \\
\hline Nieswoiste & Choroba Leśniowskiego-Crohna lub
\end{tabular}

zapalenie jelit wrzodziejące zapalenie jelita grubego obecnie lub w wywiadzie, rozpoznane przez lekarza

Zapalenie Zapalenie palców obecnie lub w wywiadzie, palców rozpoznane przez lekarza

Zapalenie Zapalenie przyczepów ścięgnistych w obrębie przyczepów pięty: ból lub bolesność palpacyjna w miejscu ścięgnistych przyczepu ścięgna Achillesa lub rozcięgna podeszwowego do kości piętowej, obecnie lub w wywiadzie

Zapalenie Zapalenie przedniego odcinka błony

przedniego naczyniowej oka obecnie lub w wywiadzie, odcinka błony potwierdzone przez okuliste naczyniowej

oka

\begin{tabular}{ll}
\hline Dobra & Ustapienie lub znaczne zmniejszenie natężenia \\
odpowiedź na & bólu pleców 24-48 godzin po przyjęciu pełnej \\
NLPZ & dawki NLPZ
\end{tabular}

\begin{tabular}{|c|c|}
\hline $\begin{array}{l}\text { Badania } \\
\text { laboratoryjne } \\
\text { lub obrazowe }\end{array}$ & Definicja \\
\hline HLA-B27 & $\begin{array}{l}\text { Wynik dodatni wg standardowych technik } \\
\text { laboratoryjnych }\end{array}$ \\
\hline $\begin{array}{l}\text { Podwyższone } \\
\text { stężenie CRP }\end{array}$ & $\begin{array}{l}\text { Stężenie powyżej górnej granicy normy, } \\
\text { po wykluczeniu innych przyczyn, przy bólu } \\
\text { pleców }\end{array}$ \\
\hline $\begin{array}{l}\text { Zapalenie } \\
\text { stawów } \\
\text { krzyżowo- } \\
\text {-biodrowych } \\
\text { w RTG }\end{array}$ & $\begin{array}{l}\text { Obustronne stopnia 2.-4. lub jednostronne } \\
\text { stopnia 3.-4., wg zmodyfikowanych kryteriów } \\
\text { nowojorskich }\end{array}$ \\
\hline $\begin{array}{l}\text { Zapalenie } \\
\text { stawów } \\
\text { krzyżowo- } \\
\text {-biodrowych } \\
\text { w MRI }\end{array}$ & $\begin{array}{l}\text { Aktywne zmiany zapalne w obrębie stawów } \\
\text { krzyżowo-biodrowych z pewnym obrzękiem } \\
\text { szpiku kostnego lub zapaleniem tkanki kostnej } \\
\text { sugerujące zapalenie stawów krzyżowo- } \\
\text {-biodrowych zwiazzane ze spondyloartropatia }\end{array}$ \\
\hline
\end{tabular}


media to grow, which are available only in some centres. In order to detect an antigen - genome of a given microorganism more and more often (although still hardly ever) a PCR method is used. An additional aspect in case of SARA is (according to international standards) the need to treat a sexual partner in order to break the vicious circle of the disease (possible re-infections) $[25,26]$.

Symptoms connected to the gastrointestinal system make ReA-patients report to gastroenterologists and infectious diseases specialists. It is believed that intestinal mucous membrane is the gate for most infections. Disease development depends on its permeability, which is conditioned genetically. In ReA studies many patients are found to have subclinical enterocolitis. Also, inflammatory diseases of intestines: ulcerative colitis, Crohn's disease, and Whipple's disease are disease entities related to ReA. Forty percent of patients suffer from episodes of diarrhoea and periodic abdominal pain. Endoscopy often confirms inflammatory lesions in the large intestine, similar to lesions in non-specific intestinal diseases (ulcerative colitis, Crohn's disease), in these patients [27].

Skin and mucosal symptoms are varied and may be red flags for diagnosing ReA. Erosions appear on oral mucosa; indolent annular ulcerative lesions (known as balanitis circinata) appear on penis glans around the urethral meatus; and circinate vulvitis appears in women; they are characteristic for ReA. They occur in $25-50 \%$ of men. Papulopustular exfoliating lesions called keratoderma blenorrhagicum may be present on feet and hands; they may be also found on the scrotal sac, penis, scalp or trunk. They occur in $20 \%$ of patients. It is difficult to differentiate them from pustular psoriasis. Psoriatic-like lesions are more often observed in HIV-patients than in other patient groups with ReA. In case of Yersinia enterocolitica-induced ReA, erythema nodosum may develop - it regards about $15 \%$ of patients. Nail lesions may suggest psoriasis [28, 29].

Lesions in the organ of sight may be varied. The most common reason why ReA-patients visit ophthalmologists is conjunctivitis that appears uni- or bilaterally in about $40 \%$ of patients, and usually at early stages of the disease. A patient complains about eye pain and redness, photophobia, and deterioration in vision. Initially, direct presence of arthrogenic microorganisms in the organ of sight was credited for those. However, having applied advanced diagnostic techniques, it was possible to isolate Chlamydia from the conjunctival sac only in $4 \%$ of patients. Other symptoms include iritis, uveitis, episcleritis, corneal ulceration, and cystoid macular oedema with posterior uveitis [30].

Symptoms connected to CNS or peripheral nerves are rare. As the disease may involve wrist joints, a car- płciową, znanego jako SARA. Zakażenia w układzie moczowo-płciowym często przebiegają bezobjawowo, ponadto niejednokrotnie uzyskuje się fałszywie ujemne wyniki badań bakteriologicznych (np. posiewu moczu lub wymazu z szyjki macicy, wymazu z cewki moczowej u mężczyzn), gdyż do wzrostu drobnoustrojów, takich jak Chlamydia trachomatis i Ureaplasma urealyticum, konieczne są specjalne podłoża dostępne jedynie w referencyjnych ośrodkach. W celu wykrycia antygenu - genomu określonego drobnoustroju, coraz częściej, ale nadal bardzo rzadko, wykorzystuje się metodę PCR. Dodatkowym zagadnieniem w przypadku SARA jest (zgodnie z międzynarodowymi standardami) konieczność leczenia partnera seksualnego w celu przerwania błędnego koła chorobowego (ewentualna ponowna infekcja) $[25,26]$.

Objawy ze strony przewodu pokarmowego powodują zgłaszanie się pacjentów z ReA do gastroenterologa oraz specjalisty chorób zakaźnych. Uważa się, że wrotami większości zakażeń jest błona śluzowa jelita. To od jej przepuszczalności, która jest uwarunkowana genetycznie, zależy rozwój choroby. W badaniach nad ReA stwierdza się u wielu chorych subkliniczne zapalenie jelit. Ponadto choroby zapalne jelit, takie jak wrzodziejące zapalenie jelita grubego, choroba Leśniowskiego-Crohna, choroba Whipple'a, są jednostkami chorobowymi pokrewnymi do ReA. U $40 \%$ chorych występują epizody biegunek i okresowe bóle brzucha. W badaniach endoskopowych $\mathrm{u}$ tych chorych stwierdza się często zmiany zapalne $\mathrm{w}$ jelicie grubym, podobne do zmian $\mathrm{w}$ nieswoistych chorobach jelit (wrzodziejące zapalenie jelita grubego, choroba Leśniowskiego-Crohna) [27].

Objawy skórno-śluzówkowe są różnorodne i mogą stanowić niejako sygnał do diagnozowania w kierunku ReA. Na błonie śluzowej jamy ustnej występują nadżerki, a na żołędzi wokół ujścia cewki moczowej - obrączkowate niebolesne zmiany z owrzodzeniami, określane jako balanitis circinata, u kobiet circinate vulvitis; są one charakterystyczne dla ReA. Występują u 25-50\% mężczyzn. Na stopach i rękach mogą być obecne grudkowo-krostkowe, łuszczące się zmiany nazywane keratoderma blenorrhagicum; mogą lokalizować się również na mosznie, prąciu, skórze głowy i tułowia. Występują u 20\% chorych. Są trudne do odróżnienia od łuszczycy krostkowej. U osób zakażonych HIV częściej niż w innych grupach chorych z ReA obserwuje się zmiany łuszczycopodobne. W części przypadków ReA wywołanego zakażeniem Yersinia enetrocolitica występuje rumień guzowaty (erythema nodosum) - dotyczy to ok. 15\% chorych. Zmiany na paznokciach mogą sugerować łuszczyce [28, 29].

Zmiany w narządzie wzroku mogą mieć bogatą symptomatologię kliniczną. Najczęstszą przyczyną 
pal tunnel syndrome with a full manifestation of entrapment neuropathy of the median nerve may develop.

Lesions in the cardiovascular system occur in $10 \%$ of ReA-patients. A cardiologist may deal with symptoms of myocarditis, various types of conduction disorders, including a complete anterograde block. Aortitis of the ascending aorta may lead to semilunar valve insufficiency of the aorta. Some patients may develop pericarditis.

Lesions in the respiratory system are rare. Patients, in whom ReA has a tendency to develop into ankylosing spondylitis, have problems with restrictive lung diseases and pulmonary fibrosis of upper lobes. Especially, limited chest movements require continual monitoring and appropriate procedures, including a co-operation with a physical therapist [31].

Treatment is directed at limiting inflammation and alleviating pain. The following are used: non-steroidal anti-inflammatory drugs, and topical intra-articular glucocorticosteroids in the areas of involved tendons and fasciae. Good results are visible with drugs modifying the disease course, i.e. first and foremost methotrexate and sulfasalazine. Other disease modifying drugs are rarely used, e.g. azathioprine or leflunomide. Sulfasalazine is considered to be especially successful in cases of peripheral arthritis and enthesopathy [32].

Macrolide antibiotics (e.g. azithromycin) or antibiotics from other groups, such as tetracyclines (e.g. lymecycline) and quinolones (e.g. ciprofloxacin) are recommended. A higher efficacy was shown with the use of combination therapy including rifampicin with azithromycin and rifampicin with tetracycline [33].

Furthermore, attempts are made to use biological drugs in cases when the disease is severe and chronic. In case of axial ReA, anti-TNF biological drugs are an accepted treatment method [34].

\section{CONCLUSIONS}

We presented a case of a male patient with reactive arthritis, in whom full-blown signs suggesting a classic Reiter's disease developed during hospitalization. A thorough examination considering a multi-organ course of the disease was significant in diagnostic and treatment process.

\section{CONFLICT OF INTEREST}

The authors declare no conflict of interest. zgłoszenia się do okulisty chorego z ReA jest zapalenie spojówek (conjunctivitis) jedno- lub obustronne, występujące u ok. 40\% osób, zazwyczaj na początku choroby. Pacjent skarży się na ból i zaczerwienienie oka, światłowstręt, pogorszenie widzenia. Początkowo przypisywano to obecności artogennych drobnoustrojów w narządzie wzroku, jednak po zastosowaniu specjalistycznych technik diagnostycznych jedynie u $4 \%$ chorych udało się wyizolować Chlamydia $\mathrm{z}$ worka spojówkowego. Inne objawy ze strony narządu wzroku to: zapalenie tęczówki (iritis), zapalenie błony naczyniowej (uveitis), zapalenie twardówki (episcleritis), owrzodzenia rogówki, cystowaty obrzęk i degeneracja plamki żółtej (cystoid macular oedema) przy zapaleniu tylnej części błony naczyniowej oka (posterior uveitis) [30].

Do rzadkości należą objawy ze strony ośrodkowego układu nerwowego lub nerwów obwodowych. Ze względu na zajęcie procesem chorobowym stawów nadgarstka może wystąpić zespół kanału nadgarstka z pełnym obrazem uciskowej neuropatii nerwu pośrodkowego.

Zmiany w układzie sercowo-naczyniowym występują u $10 \%$ chorych z ReA. Kardiolog może stwierdzić objawy zapalenia mięśnia serca (myocarditis) z różnego typu zaburzeniami przewodnictwa, aż do całkowitego bloku przedsionkowo-komorowego. Zapalenie aorty wstępującej może prowadzić do niedomykalności zastawek półksiężycowatych aorty. U nielicznych chorych występuje zapalenie osierdzia.

Zmiany w układzie oddechowym należą do rzadkości. U pacjentów z tendencją do przechodzenia ReA w zesztywniające zapalenie stawów kręgosłupa problemem jest restrykcyjna niewydolność oddechowa i włóknienie górnych płatów płuc. Szczególnie ograniczenie ruchomości klatki piersiowej wymaga stałego monitorowania i odpowiedniego postępowania, w tym współpracy ze specjalistą rehabilitacji [31].

Leczenie ukierunkowane jest na ograniczenie zapalenia i łagodzenie dolegliwości bólowych. Podaje się niesteroidowe leki przeciwzapalne, glikokortykosteroidy stosowane miejscowo w okolice zajętych ścięgien i powięzi. Dobre rezultaty przynosi stosowanie leków modyfikujących przebieg choroby, czyli metotreksatu i sulfasalazyny. Rzadko wykorzystuje się inne leki modyfikujące przebieg choroby, np. azatioprynę i leflunomid. Sulfasalazyna uważana jest za szczególnie skuteczną w przypadku obwodowego zapalenia stawów i entezopatii [32].

Zaleca się antybiotyki z grupy makrolidów (np. azytromycynę) lub innych grup, takich jak tetracykliny (np. limecyklina) i chinolony (np. cyprofloksacyna). Stwierdzono większą skuteczność terapii skojarzonej ryfampicyną z azytromycyną oraz ryfampicyną z tetracykliną [33]. 
Podejmuje się próby stosowania leków biologicznych w przypadkach ciężkiego, przewlekłego przebiegu. W postaci osiowej ReA leki biologiczne z grupy anty-TNF są uznaną metodą leczenia [34].

\section{WNIOSKI}

Przedstawiono przypadek pacjenta z reaktywnym zapaleniem stawów, u którego w trakcie hospitalizacji wystąpiły cechy sugerujące pełnoobjawową, klasyczną postać choroby Reitera. W procesie diagnostyki i leczenia ważne było dokładne badanie uwzględniające wielonarządowy przebieg tej choroby.

\section{KONFLIKT INTERESÓW}

Autorki nie zgłaszają konfliktu interesów.

\section{References}

\section{Piśmiennictwo}

1. Curcic Z.A.: Ankylosing spondylitis initiated a reactive arthritis. Ann Rheum Dis 2001, 60 Suppl 1, 216.

2. Garwolińska H.: Reaktywne zapalenie stawów - diagnostyka i obraz kliniczny. Alerg Astma Immun 1999, 4, 114-115.

3. Childs S.G.: Reactive arthritis. Immune-mediated synovitis or joint infection. Orthop Nurs 2004, 23, 267-273.

4. Sigal L.H.: Update on reactive arthritis. Rheum Dis 2001, 50, 1-4.

5. Bernacka K.: Reaktywne zapalenie stawów. S. Mackiewcz, I. Zimmermann-Górska (eds.), PZWL, Warsaw, 1995, 232-238.

6. Reveille J.D.: An update on the contribution of the MHC to as susceptibility. Clin Rheumatol 2014, 33, 749-775.

7. Reveille J.D.: Genetics of spondyloarthritis beyond the MHC. Nat Rev Rheumatol 2012, 8, 296-304.

8. Horner P.J., Martin D.H.: Mycoplasma genitalium infection in men. J Infect Dis 2017, 15, 396-405.

9. Asakawa J., Kobayashi S., Kaneda K.: Reactive arthritis after influenza vaccination: report of a case. Mod Rheumatol 2005, 15, 283-285.

10. Bartolome Pacheco M.J., Martinez-Taboada V.M., Blanco R.: Reactive arthritis after BCG immunotherapy: T cell analysis in peripheral blood and synovial fluid. Rheumatology 2002, 41, 1119-1125.

11. Garg A.X., Pope J.E., Thiessen-Philbrook H.; Walkerton Health Study Investigators: Arthritis risk after acute bacterial gastroenteritis. Rheumatology 2008, 47, 200-204.

12. Rudwaleit M., Richter S., Braun J., Sieper J.: Low incidence of reactive arthritis in children following a Salmonella outbreak. Ann Rheum Dis 2001, 60, 1055-1057.

13. Li C.W., Ma J.J., Yin J.: Reiter's syndrome in children: a clinical analysis of cases. Zhonghua Er Ke Za Zhi 2010, 48, $212-215$.

14. Adizie T., Moots R.J., Hodkinson B., French N., Adebajo A.O.: Inflammatory arthritis in HIV positive patients: a practical guide. BMC Infect Dis 2016, 3, 1-16.

15. de Vries HJ.: Skin as an indicator for sexually transmitted infections. Clin Dermatol 2014, 32, 196-208.

16. Silva I., Mateus M., Branco J.C.: Poncet's disease: a symmetric seronegative polyarthritis with enthesopathy refractory to the therapy. Acta Reumatol Port 2013, 38, 192-195.

17. Omonge E., Otieno F., Kubo M., Shiruli B.: Poncet's disease in human immunodeficiency virus: a case report. BMC Res Notes 2017, 203-210.

18. Eliçabe R.J., Cargnelutti E., Serer M.I, Stege P.W., Valdez S.R., Toscano M.A., et al.: Lack of TNFR p55 results in heightened expression of IFN-gamma and IL-17 during the development of reactive arthritis. J Immunol 2010, 185, 448-452.

19. Martelli-Palomino G., Paoliello-Paschoalato A.B., Crispim J.C., Rassi D.M., Oliveira R.D., Louzada P., et al.: DNA damage increase in peripheral neutrophils from patients with rheumatoid arthritis is associated with the disease activity and the presence of shared epitope. Clin Exp Rheumatol 2017, 35, 247-254.

20. Mayordomo A.C., Silva J.E., Gorlino C.V., Arias J.L., Berón W., Di Genaro M.S.: IL-12/23p40 overproduction by dendritic cells leads to an increased Th1 and Th17 polarization in a model of Yersinia enterocolitica-induced reactive arthritis in TNFRp55-/- mice. PLoS One 2018, 3, 1-13.

21. Sieper J., Braun J., Wu P., Kingsley G.: Alteration in T cell/macrophage ratio may reveal lymphocyte proliferation specific for the triggering antigen in reactive arthritis. Scand J Immunol 1992, 36, 427-434.

22. Rudwaleit M., van der Heijde D., Landewé R. Listing J., Akkoc N., Brandt J., et al.: The development of Assessment of SpondyloArthritis International Society classification criteria for axial spondyloarthritis (part II): validation and final selection. Ann Rheum Dis 2009, 68, 777-783.

23. Rudwaleit M.: New approaches to diagnosis and classification of axial and peripheral spondyloarthritis. Curr Opin Rheumatol 2010, 22, 375-380.

24. van den Berg R., van der Heijde D.M.: How should we diagnose spondyloarthritis according to the ASAS classification criteria: a guide for practicing physicians. Pol Arch Med Wewn 2010, 120, 452-457. 
25. Szechliński J., Garwolińska H., Bernacka K.: Spondyloartropatie. Reumatologia 2000, 38, 68-73.

26. Wollenhaupt J., Kolbus F., Weissbrodt H., Schneider C., Krech T., Zeidler H.: Manifestation of Chlamydia induced arthritis in patients with silent versus symptomatic urogenital chlamydial infection. Clin Exp Rheum 1995, 13, 453-458.

27. Schneider J.M., Matthews J.H., Graham B.S.: Reiter's syndrome. Cutis 2003, 71, 198-200.

28. Flückiger R.: What is your diagnosis? Balanitis erosiva circinata in Reiter's disease. Schweiz Rundsch Med Prax 1990, 79, 1-2.

29. Haake N., Altmeyer P.: Vulvovaginitis circinata in Reiter's disease. Hautarzt 1988, 39, 748-759.

30. Suresh P.S.: Bilateral disciform keratitis in Reiter's syndrome. Indian J Ophthalmol 2016, 64, 685-687.

31. Toledano E., García de Yébenes M.J., González-Álvaro I., Carmona L.: Severity indices in rheumatoid arthritis: a systematic review. Reumatol Clin 2017, 11, 30180-30188.

32. Barber C.E., Kim J., Inman R.D., Esdaile J.M., James M.T.: Antibiotics for treatment of reactive arthritis: a systematic review and metaanalysis. J Rheumatol 2013, 40, 916-928.

33. Eggens U., Sieper J., Braun J.: Principles of therapy in reactive arthritis. Wien Klin Wochenschr 1994, 106, 259-264.

34. Nam J., Emery P.: Aspects of TNF inhibitor therapy in rheumatoid arthritis. Mod Rheumatol 2010, 20, 325-330.

Received: 14.08 .2018

Accepted: 18.12.2018

Otrzymano: 14.08 .2018 r.

Zaakceptowano: 18.12.2018 r.

How to cite this article

Biało-Wójcicka E., Rutkowska K., Wysocka-Dubielecka K.: Reactive arthritis - an interdisciplinary issue. Dermatol Rev/Przegl Dermatol 2018, 105, 726-737. DOI: https://doi.org/10.5114/dr.2018.80842. 